\title{
Conceptualizing the (non) users of the internet
}

\author{
Sora Park \\ University of Canberra \\ Australia \\ sora.park@canberra.edu.au
}

\author{
Catherine Middleton \\ Ryerson University \\ Canada \\ catherine.middleton@ryerson.ca
}

\author{
Matthew Allen \\ Deakin University \\ Australia \\ matthew.allen@deakin.edu.au
}

\begin{abstract}
Most studies about internet use examine how usage differs among users and why. Less attention has been paid to the varied degrees of non-use or low levels of use. Non-adopters of digital media are usually understood as not having access to digital media. However, there is a considerable variation among them with regards to how and why they lack the connectivity. Furthermore, it is important to acknowledge those who do have access but use the internet only in a limited capacity. Digital exclusion does not only occur among those who do not have access but expands to those who cannot use the internet effectively. A new type of digital exclusion is emerging due to this variation of usage and appropriation. We propose a nuanced approach in defining the various levels of internet non- and low use. Rather than highlighting how social exclusion, therefore the lack of connectivity, leads to digital exclusion, this paper looks at the various contexts in which people might be digital disengaged and therefore digitally excluded.
\end{abstract}

\section{Keywords}

digital divide; digital exclusion; internet use; broadband; non-users

\section{Introduction}

We can no longer separate the physical and digital world, and the interplay between located and distributed communications is becoming more and more significant every day. The internet and related networks gives rise, in the words of Rainie and Wellman (2012), to a new "social operating system", effectively imbricated into our daily lives, both in its absence and presence. Effective use of digital networks has become crucial for social connectedness, civic engagement and economic opportunities. The benefits of being connected range from productivity or employment gains in work, through to the capacity to engage meaningfully in social relations of both a private and public nature. In particular, as communities exploit the effectiveness of the internet, civic participation is coming to depend on connectivity (Hargattai \& Walejko, 2008). Gaining and spending social capital through digital networks now defines the information society.

Broadband connectivity, designed and built to provide the technologies for populations to embrace inclusion in a networked information society, has also had a paradoxical opposite outcome. Uneven availability of technology, limited user skills and, most of all, ill-distributed awareness of the potential in such networks has meant increased risks of exclusion for some, even as others benefit. The Australian government for example envisions social inclusion being increased through its new broadband program, the National Broadband Network (NBN), believing that by extending broadband connectivity it is building a nation in which every citizen has the opportunity to participate in the community (Australian Social Inclusion Board, 2012). However, merely providing home access to technologies cannot overcome longstanding barriers to use. For instance, existing socio-economic disadvantage warrants continued attention in its relation to internet use (Livingstone \& Helsper, 2007). Many who are socially excluded also live in communities with poor broadband access, with these two factors often times reinforcing each other (Dailey, et al, 2010). Income, employment, geographic area, gender and age all play a role here (Holloway, 2002; Lengsfeld, 2011; Holfeld et al, 2008; Hargittai \& Shafer, 2006; Asthana, Halliday \& Gibson, 2009).

Nonetheless, we cannot assume existing social exclusion is exactly the same as digital exclusion. We need to examine why people are outside the digital mainstream, and determine the extent to which this is due to reasons of exclusion or choice. By exploring the implications such lack of participation has 
on their everyday lives, we can begin to bridge the second level digital divide that occurs when physical access is less of an issue. As ubiquitous, affordable network connectivity is provided through initiatives like Australia's NBN, the question remains as to why some people do not take it up, or make limited use of it, and thus become part of the digitally excluded. While appearing connected, they are not techno-socially connected. As access issues recede, we need to carefully consider "non and low users" - those who have limited or partial uses of the technology.

\section{Revisiting the digital divide}

Scholars have acknowledged that the dichotomy between haves and have-nots is simplistic (BarzilaiNahon, 2006; Middleton, Veenhof \& Leith, 2010; Selwyn, 2003; Selwyn, 2004; Sourbati, 2009; Tsatsou, 2011; Verdegem \& Verhoest, 2009). A more useful idea is to see the information society creating a continuum of digital inclusion and exclusion, (Warschauer 2002; Lenhart and Horrigan, 2003; Eynon \& Geniets, 2012). Rather than positioning "access" as the main determinant of social exclusion, we should examine how and how much people use digital technologies particularly in relation to the different levels of skills that result in divergent uses (Dobransky \& Hargittai, 2006; Vicente \& Lopez, 2010). This second level digital divide, amplified by the multiple levels of access, use and appropriation of technologies (Livingstone \& Helsper, 2007; Park, 2012; Selwyn, 2004; Tsatsou, 2011; van Dijk, 2006a; Verdegem \& Verhoest, 2009), must be understood now as a question of the quality and extent of digital engagement, the realization of potentials, not just the connecting and skilling of a receptive population (see Tsatsou, 2011). Gurstein's (2003) concept of effective use extends the access issue to larger concerns of how uses can benefit individuals and communities, shifting the focus to the entire process of harnessing infrastructure, hardware, software and social organizational elements for collective benefit. In order to use the online resources for beneficial activities, one must have constant access and the motivation to use various services. Meaningful use, as discussed by Ito, et al, (2008), can also reframe our awareness that access and use are not, of themselves, sufficient.

\section{Reconceptualising non users}

Studies on non adopters of digital technologies usually attempt to find out why people choose not to be connected and find no uniform reason. But they have shown that socio-economic status and associated costs of adopting new technologies are less significant than factors such as: skills and efficacy (World Internet Project, 2010), motivation and disinterest (Verdegem \& Verhoest, 2009; Zickuhr, 2010), and attitudes and personal traits (Davis, 1989; Matei \& Ball-Rokeach, 2003; Stanley, 2003; Verdegem \& Verhoest, 2009; Vishwanath \& Golohaber, 2003).

"Non-users" have been variously labeled and constructed as subjects of research: dropouts (Katz, Rice \& Aspen, 2001), laggards (Goldenberg \& Oreg, 2007), unadopters (Dailey et al, 2010), narrow frequent users, occasional users and non-users (Selwyn et al, 2005; Selwyn, 2006), unengaged and marginalized (Longley et al, 2006), non- or sporadic users (Brandtzaeg, Heim \& Karahasanovic, 2010) and lapsed users (Eynon \& Geniets, 2012). Such people are hard to understand as a collective, as well, since many move back and forth between being users and non users (Mehra, Merkel \& Bishop, 2004).

According to Mossberger et al (2008), digital citizenship requires online participation. For this reason, they define digital citizens as those who use the internet every day. Infrequent or occasional users either might not have the skills to use the internet effectively or do not have the opportunity to develop such skills. Allen's (2010) experience of connectivity provides a useful the framework for studying internet uses and non-uses. He defines connectivity as "having and using internet connection at home" (p. 351). The experience of connectivity is the ways in which people utilize the internet to achieve a variety of outcomes in their everyday lives.

Brandtzaeg (2010) defines media behavior as the totality of human behavior in relation to new media use, which includes both the frequency of use (the level of participation) and the form of use (content and activity preference). The latter is similar to the quality of use, which can largely be determined by the motivation of the users. 
By examining how and how much people use the internet and using such measures to provide a new framework of researching uses and non uses of the internet, we can link how digital engagement is related to digital inclusion among the various user typologies. Similarly, when we examine non- and low users of the internet, the context in which digital disengagement may lead to digital exclusion must be considered.

\section{References}

Asthana, Sheena, Halliday, Joyce, \& Gibson, Alex. (2009). Social exclusion and social justice: a rural perspective on resource allocation. Policy \& Politics, 37, 201-214.

Australian Social Inclusion Board. (2012). Social Inclusion in Australia: How Australia is faring 2012 (2nd ed.): Australian Government, Department of the Prime Minister and Cabinet.

Barzilai-Nahon, Karine. (2006). Gaps and Bits: Conceptualizing Measurements for Digital Divide/s. The Information Society, 22(5), 269-278.

Brandtzaeg, Petter Bae. (2010). Towards a unified Media-User Typology (MUT): A meta-analysis and review of the research literature on media-user typologies. Computers in Human Behavior, 26(5), 940-956.

Brandtzaeg, Petter Bae, Heim, Jan, \& Karahasanovic, Amela. (2010). Understanding the new digital divide: A typology of Internet users in Europe. International Journal of Human-Computer Studies, 69, 123-138.

Dailey, Dharma, Bryne, Amelia, Powell, Alison, Karaganis, Joe, \& Chung, Jaewon. (2010). Broadband Adoption in Low-Income Communities: Social Science Research Council.

Davis, Fred D. (1989). Perceived Usefulness, Perceived Ease of Use, and User Acceptance of Information Technology. MIS Quarterly, 13, 319-340.

Dobransky, Kerry, \& Hargittai, Eszter. (2006). The disability divide in internet access and use. Information, Communication \& Society, 9, 313-334.

Eynon, R. and Geniets, A. (2012) On the Periphery? Understanding Low and Discontinued Internet Use Amongst Young People in Britain. Report for the Nominet Trust.

Goldenberg, Jacob, \& Oreg, Shaul. (2007). Laggards in disguise: Resistance to adopt and the leapfrogging effect. Technological Forecasting and Social Change, 74(8), 1272-1281.

Gurstein, M. (2003). Effective Use: A Community Informatics Strategy Beyond the Digital Divide. First Monday, 8(12).

Hargittai, Eszter, \& Shafer, Steven. (2006). Differences in Actual and Perceived Online Skills: The Role of Gender. Social Science Quarterly, 87(2), 432-448

Hargittai, Eszter, \& Walejko, Gina. (2008). The participation divide: Content creation and sharing in the digital age. Information, Communication \& Society, 11(2), 239 - 256.

Hohlfeld, T. N., Ritzhaupt, A. D., Barron, A. E., \& Kemker, K. (2008). Examining the digital divide in K-12 public schools: Four-year trends for supporting ICT literacy in Florida. Computers \& Education, 51(4), $1648-1663$.

Holloway, Darren. (2002). Disparities in Internet access: a case study of the digital divide in Western Sydney. Australian Journal of Social Issues, 37(1), 51-69.

Horrigan, John. (2010). Broadband Adoption and Use in America OBI Working Paper Series (Vol. 1): Federal Communications Commission.

Ito, M., Horst, H., Bittanti, M., boyd, d., Herr-Stephenson, B., Lange, P., Pascoe,C.J., \& Robinson, L. (2008). Living and Learning with New Media: Summary of Findings from the Digital Youth Project Building the Field of Digital Media and Learning. The John D. and Catherine T. MacArthur Foundation.

Katz, J. E. , Rice, R. E., \& Aspen, P. . (2001). The Internet, 1995-2000. American Behavioral Scientist, 45(3), 405-419

Livingstone, Sonia, \& Helsper, Ellen. (2007). Gradations in digital inclusion: children, young people and the digital divide. New Media \& Society, 9(4), 671-696 
Selected Papers of Internet Research 14.0, 2013: Denver, USA

Longley, PA, Webber, R, \& Li, C. (2006). The UK geography of the e-society: A national classification Centre for Advanced Spatial Awareness (UCL), London, UK: University College London.

Rainie, Lee \& Wellman, Barry. (2012). Networked: The New Social Operating System Cambridge, MA.: MIT Press

Matei, Sorin, \& Ball-Rokeach, Sandra. (2003). The Internet in the Communication Infrastructure of Urban Residential Communities: Macro- or Mesolinkage? Journal of Communication, 53(4), 642-657.

Mehra, Bharat, Merkel, Cecelia, \& Bishop, Ann Peterson. (2004). The internet for empowerment of minority and marginalized users. New Media \& Society, 6(6), 781-802

Middleton, C., Veenhof, B., \& Leith, J. (2010). Intensity of Internet Use in Canada: Understanding Different Types of Users. Ottawa: Statistics Canada - Business Special Surveys and Technology Statistics Division Working Papers.

Mossberger, Karen, Tolbert, Caroline J., \& McNeal, Ramona S. (2008). Digital Citizenship: The Internet, Society, and Participation. Cambridge, MA: MIT Press.

Park, S. (2012). Dimensions of digital media literacy and the relationship to social exclusion. Media International Australia, 142, 87-100.

Putnam, R.D. (2000). Bowling Alone: The Collapse and Revival of American Community. New York: Simon and Schuster.

Selwyn, Neil. (2003). Apart from technology: understanding people's non-use of information and communication technologies in everyday life. Technology in Society, 25, 99-116.

Selwyn, Neil. (2004). Reconsidering Political and Popular Understandings of the Digital Divide. New Media \& Society, 6(3), 341-362

Selwyn, Neil. (2006). Digital division or digital decision? A study of non-users and low-users of computers. Poetics, 34(4-5), 273-292.

Selwyn, Neil, Gorard, Stephen, \& Furlong, John. (2005). Whose Internet is it Anyway? Exploring Adults' (Non)Use of the Internet in Everyday Life. European Journal of Communication, 20, 5-26.

Sourbati, Maria. (2009). Media Literacy and Universal Access in Europe. The Information Society: An International Journal, 25(4), 248 - 254.

Stanley, Laura D. (2003). Beyond Access: Psychosocial Barriers to Computer Literacy. Special Issue: ICTs and Community Networking. The Information Society: An International Journal, 19(5), 407 - 416.

Tsatsou, Panayiota. (2011). Digital divides revisited: what is new about divides and their research? Media, Culture \& Society, 33(2), 317-331.

van Dijk, J. (2006). Digital divide research, achievements and shortcomings. Poetics, 34(4-5), 221-235.

Verdegem, Pieter, \& Verhoest, Pascal. (2009). Profiling the Non-user: Rethinking Policy Initiatives Stimulating ICT Acceptance. Telecommunications Policy, 33(10-11), 642-652.

Vicente, Maria Rosalia, \& Lopez, Ana Jesus. (2010). A Multidimensional Analysis of the Disability Digital Divide: Some Evidence for Internet Use. Information Society, 26, 48-64.

Vishwanath, Arun, \& Golohaber, Gerald M. (2003). An examination of the factors contributing to adoption decisions among late-diffused technology products. New Media \& Society, 5, 547-572.

Warschauer, Mark. (2002). Reconceptualising the digital divide First Monday, 7(1).

Zickuhr, Kathryn. (2010). Generations 2010: Pew Research Center's Internet \& American Life Project. 